ISSN 2089-8673

Jurnal Nasional Pendidikan Teknik Informatika (JANAPATI)

Volume 2, Nomor 1, Maret 2013

\title{
Pengembangan Text to Digital Image Converter Untuk Dokumen Aksara Bali
}

\section{Oleh}

\author{
I Dewa Ayu Made Sartini, Made Windu Antara Kesiman, S.T., M.Sc, I Gede \\ Mahendra Darmawiguna, S.Kom., M.Sc \\ Jurusan Pendidikan Teknik Informatika \\ Fakultas Teknik dan Kejuruan \\ Universitas Pendidikan Ganesha \\ Email : gek_ayu32@yahoo.com
}

\begin{abstract}
ABSTRAK
Bali merupakan sebuah daerah yang memiliki berbagai macam kebudayaan. Salah satunya adalah sistem penulisannya menggunakan aksara Bali. Aksara Bali banyak digunakan dalam kehidupan sehari $\ddot{i}$ hari yaitu digunakan untuk keperluan penulisan naskah suci peninggalan sejarah, penulisan nama jalan, serta digunakan dalam bidang agama yaitu dalam pelaksanaan upacara adat Bali. Namun walaupun penggunaan aksara Bali sangat penting dalam kehidupan di Bali, saat ini sangat sedikit orang yang mampu menulis dengan aksara Bali. Untuk membantu dalam memahami penulisan menggunakan aksara Bali maka dilakukanlah penelitian ini yang bertujuan untuk merancang dan mengimplemantasikan sebuah aplikasi text to digital image converter untuk dokumen aksara Bali.

Perangkat lunak ini hanya menangani proses konversi untuk aksara wianjana saja. Proses mengkonversi dari dokumen dalam bentuk huruf Latin menjadi gambar dokumen aksara Bali dilakukan melalui beberapa tahapan yaitu tahap pertama menghitung panjang karakter dokumen yang diinputkan. Tahap kedua memecah dokumen yang diinpukan menjadi suku kata. Tahap ketiga yaitu melakukan pengecekan jika terdapat suku kata asing yang ditemukan pada proses memecah suku kata, maka akan dirubah kedalam ejaan aksara Bali. Tahap keempat menentukan posisi dari suku kata tersebut apakah termasuk posisi talawia (atas), murdania (tengah), dantia (bawah). Tahap keempat yaitu memcocokkan antara suku kata dengan gambar aksara Bali yang telah disimpan sebelumnya dalam sebuah folder. Tahap terakhir adalah penempatan gambar aksara Bali sesuia dengan posisi gambar aksara Bali tersebut.

Hasil penelitian ini adalah sebuah aplikasi text to digital image converter untuk dokumen aksara Bali. Perangkat lunak ini dibuat dengan bahasa pemrograman Borland Delphi 7.0. Perangkat lunak ini juga diimplementasikan dan telah diujicobakan pada sistem operasi berbasis Windows.
\end{abstract}

Kata-kata kunci: text to digital image converter, aksara Bali, aplikasi 
ISSN 2089-8673

Jurnal Nasional Pendidikan Teknik Informatika (JANAPATI)

Volume 2, Nomor 1, Maret 2013

\section{Pendahuluan}

Indonesia merupakan negara kepulauan yang terdiri dari banyak pulau dan memiliki berbagai macam suku bangsa, bahasa, adat istiadat atau yang sering kita sebut dengan kebudayaan. Salah satu daerah yang memiliki beranekaragam kebudayaan adalah Bali, Bali memiliki tata cara penulisan yang khusus dalam penulisan bahasa Bali yaitu yang disebut dengan aksara Bali. Aksara Bali sendiri banyak digunakan dalam kehidupan di Bali seperti dalam bidang agama (Hindu). Aksara Bali juga berfungsi dalam bidang pemerintahan yaitu digunakan untuk menuliskan naskah suci peninggalan sejarah, menuliskan nama jalan dan masih banyak fungsi dari aksara Bali.

Hampir sebagian besar orang yang tinggal di Bali mampu berkomunikasi dengan menggunakan bahasa Bali tapi hanya sedikit orang yang mampu menulis dengan aksara Bali. Hal tersebut terjadi karena tata cara penulisan aksara Bali sangat kompleks, pendidikan penulisan aksara Bali hanya didapatkan pada bangku Sekolah Dasar (SD), dan semakin berkurang orang yang ahli dalam penulisan aksara Bali, sehingga penggunaan aksara Bali kini semakin jarang digunakan dan lingkup pemakaiannya semakin sempit.

Keberlangsungan penggunaan aksara Bali harus dipertahankan melalui empat jalur, yaitu agama (Hindu), pendidikan (informal, formal dan nonformal), kebudayaan, dan teknologi. Dalam bidang teknologi untuk melestarikan penggunaan aksara Bali diperlukan sebuah alat untuk dapat membantu untuk memahami penulisan bahasa Bali menggunakan aksara Bali. Alat bantu yang dimaksud adalah komputer. Upaya untuk melakukan komputerisasi sudah dilakukan sebelumnya yaitu dengan cara memasukaan aksara Bali dalam standar karakter Unicode dan menghasilkan font Bali Simbar yang bisa digunakan pada saat menggunakan MS. Word dengan cara menginstal font tersebut. Font Bali Simbar masih memiliki beberapa kelemahan dalam penggunaannya banyak menggunakan perpaduan keyword sehingga semua fungsi key shortcut tidak bisa dilakukan seperti CTRL+C untuk mencopy tulisan CTRL+F untuk pencarian kata dan berbagai fungsi shortcut lainnya sehingga semuanya terpaksa menggunakan mouse.

Berdasarkan latar belakang di atas, maka penulis memiliki inisiatif untuk mengembangkan aplikasi text to digital image converter untuk dokumen aksara Bali 
ISSN 2089-8673

Jurnal Nasional Pendidikan Teknik Informatika (JANAPATI)

Volume 2, Nomor 1, Maret 2013

yang diharapkan dengan adanya pengembangan aplikasi tersebut dapat membantu melestarikan kebudayaan aksara Bali.

\section{Metodologi}

\subsection{Aksara Bali}

Aksara merupakan salah satu jenis simbol visual dari suatu bahasa. Bahasa Bali dapat ditulis dengan dua jenis simbol yaitu dengan aksara Bali dan tulisan Bali Latin. Menurut sejarah aksara Bali, aksara Bali diambil dari huruf Jawa, sedangkan huruf Jawa mengambil dari huruf Pallawa/Dewanegari, hanya bentuknya secara evolusi sudah berubah sehingga menjadi aksara yang sering dipakai saat ini (Tinggen, $1993: 1$ ).

\subsubsection{Sejarah Aksara Bali}

Sejarah aksara atau huruf Bali tidak terpisahkan dengan keberadaan aksara yang ada di India. Di dalam kitab Svara-Vyanjana, tulisan Prof. Raghu Vira (1956), disebutkan bahwa India pertama kali dikenal aksara yang disebut aksara Karosti. Dari aksara ini kemudian berkembang menjadi aksara Brahmi. Aksara inilah yang menjadi cilak bakal dari aksara Dewanagari dan aksara Pallawa. Aksara Dewanagari lebih berkembang di India Utara, sedangkan aksara Pallawa lebih banyak dipergunakan oleh penduduk di India Selatan. Aksara Dewanagari dipergunakan untuk menulis tulisan terutama yang berbahasa Sansekerta, sedangkan aksara Pallawa lebih banyak dipergunakan untuk menulis naskah berbahasa Pallawa. Di India aksara Dewanagari dipergunakan dalam bahasa yang berbeda-beda, selain bahasa Sansekerta, juga di dalam bahasa Apabhramsa, Marathi, Nepali, Pali, Prakrit, dan bahasa kebangsaan India, yaitu Hindu.

\subsubsection{Pembagian Aksara Bali}

Berdasarkan atas bentuk dan fungsinya, aksara Bali dibagi atas dua jenis yakni aksara biasa dan aksara suci. Aksara biasa ini terdiri atas aksara wreastra dan swalalita. Disebut aksara biasa karena telah terbiasa dipergunakan oleh masyarakat Bali di dalam tulis-menulis untuk memenuhi kebutuhan hidupnya sehari-hari dalam berhubungan dengan sesama melalui aksara. Sedangkan aksara suci terbagi atas dua kelompok, yakni aksara wijaksara (di Bali lebih dikenal dengan sebutan bijaksara) dan mondre. Aksara 
ISSN 2089-8673

Jurnal Nasional Pendidikan Teknik Informatika (JANAPATI)

Volume 2, Nomor 1, Maret 2013

bijaksara atau wijaksara pada hakikatnya adalah aksara swalalita yang diberi pengangge atau busana aksara. Sedangkan aksara modre, lebih tepat disebut lukisan, karena merupakan bentukan dari aksara swalalita ditambahi dengan beberapa pengangge aksara serta lukisan, sehingga menjadi ñaksara matiò, sulit untuk membacanya.

\subsubsection{Aksara Biasa}

Yang dimaksud dengan aksara biasa ini adalah aksara atau huruf Bali yang biasa dipergunakan dalam penulisan untuk memenuhi kebutuhan hidup sehari-hari dalam berkomunikasi dan berkesusastreraan. Kerap juga aksara ini (wreastra dan swalalita) disebut aksara hanacaraka (anacaraka). Aksara Bali ini terdiri atas : aksara wreastra dan swalalita.

\subsubsection{Aksara Wreastra}

Aksara ini dipergunakan untuk menulis masalah kehidupan sehari-hari, seperti menulis barbagai catatan, kesusasteraan, ilmu, hukum, perjanjian, surat-menyurat dan lain-lain. Jumlah aksara ini di Bali adalah 18 buah (hana caraka, gata mangaba sawala, pada jayanya), sedangkan di Jawa ada sebanyak 20 buah (hana caraka data sawala pada jayanya maga batanga). Dua aksara kelebihan dari aksara Jawa ini berupa aksara da madu $\left({ }_{\mathrm{a}}\right)$ dan ta tatik(.). Apa karena ini maka lidah orang Bali sulit menyebutkan $\mathrm{t}$ dan d. Aksara wreastra terdiri atas aksara suara (vokal, huruf hidup) dan aksara wianjana (konsonan, huruf mati).

\subsubsection{Aksara Suara Wreastra}

Aksara vokal atau suara dari aksara wreastra (tidak temasuk aksara vokal dari aksara swalalita) yang dibentuk dari aksara wisarga $(\mathrm{a}=\mathrm{h})$ diberi pengangge aksara suara terdiri dari 6 buah dapat dilihat pada Tabel 2.1.

Tabel 2.1 : Aksara Suara Wreastra (Sumber : Nala, 2006).

\begin{tabular}{|l|l|l|l|l|l|}
\hline No & Aksara Latin & $\begin{array}{c}\text { Aksara Suara } \\
\text { Wreastra }\end{array}$ & No & Aksara Latin & $\begin{array}{c}\text { Aksara Suara } \\
\text { Wreastra }\end{array}$ \\
\hline 1 & a & H & 4 & e & Eh \\
\hline 2 & i & Hi & 5 & o & eho \\
\hline 3 & u & Hu & 6 & ə & h) \\
\hline
\end{tabular}


ISSN 2089-8673

Jurnal Nasional Pendidikan Teknik Informatika (JANAPATI)

Volume 2, Nomor 1, Maret 2013

\subsubsection{Aksara Wianjana Wreastra}

Aksara konsonan atau wianjana dari aksara wreastra (tidak termasuk aksara konsonan dari aksara swalalita), yang terdiri atas 18 buah. Dalam penulisan aksara wianjana terdapat apa yang disebut dengan nama gantungan dan gempelan. Gantungan adalah suatu bentuk aksara Bali bila mengikuti konsonan (aksara wianjana) pada suku kata tertutup. Gantungan ini ditulis di bawah suku kata atau aksara yang mendahuluinya namun gantungan tidak berlaku untuk konsonan sa dan pa. Untuk penulisan konsonan sa dan pa yang mengikuti suku kata tertutup disebut dengan gempelan, gempelan adalah bentuk aksara yang dirangkaikan pada aksara di depannya. Bentuk dari aksara konsonan atau aksara wianjana wreastra, gantungan, dan gempelan dapat dilihat pada Tabel 2.2.

Tabel 2.2 : Aksara Wianjana Wreastra (Sumber : Nala, 2006).

\begin{tabular}{|c|c|c|c|c|}
\hline \multirow{2}{*}{ No } & \multirow{2}{*}{ Aksara Latin } & \multicolumn{3}{|c|}{ Aksara Wianjana Wreastra } \\
\hline & & Aksara Wianjana & Gantungan & Gempelan \\
\hline 1 & ha & $\mathrm{H}$ & $\cdots \cdots \cdots \bar{A}$ & \\
\hline 2 & na & $\mathrm{N}$ & $\cdots \cdots \cdots \hat{A}$ & \\
\hline 3 & $\mathrm{ca}$ & $\mathrm{C}$ & $\cdots \cdots \cdots \cdot C$ & \\
\hline 4 & $\mathrm{ra}$ & $\mathrm{R}$ & $\cdots \cdots \cdots \cdot \bar{E}$ & \\
\hline 5 & ka & K & $\cdots \cdots \cdots$ & \\
\hline 6 & ga & $\mathrm{G}$ & ……á & \\
\hline 7 & ta & $\mathrm{T}$ & ……' & \\
\hline 8 & ma & M & 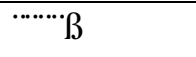 & \\
\hline 9 & nga & 1 & $\cdots \cdots \cdots a ̊$ & \\
\hline 10 & ba & B & $\cdots \cdots \cdots \cdot a ̃$ & \\
\hline 11 & $\mathrm{sa}$ & $\mathrm{S}$ & & ü \\
\hline 12 & wa & $\mathrm{W}$ & "....'.'U & \\
\hline 13 & la & $\mathrm{L}$ & $\cdots \cdots \cdots \cdot \mathrm{P}$ & \\
\hline
\end{tabular}


ISSN 2089-8673

Jurnal Nasional Pendidikan Teknik Informatika (JANAPATI)

Volume 2, Nomor 1, Maret 2013

\begin{tabular}{|c|c|c|c|c|}
\hline \multirow{2}{*}{ No } & \multirow{2}{*}{ Aksara Latin } & \multicolumn{3}{|c|}{ Aksara Wianjana Wreastra } \\
\hline & & Aksara Wianjana & Gantungan & Gempelan \\
\hline 14 & $\mathrm{pa}$ & $\mathrm{P}$ & & $\mathfrak{X}$ \\
\hline 15 & $\mathrm{da}$ & $\mathrm{D}$ & $\cdots \cdots \cdot \overline{\mathrm{N}}$ & \\
\hline 16 & ja & $\mathrm{J}$ & "é & \\
\hline 17 & ya & $\mathrm{Y}$ & $\cdots \cdots \cdot \hat{\mathrm{e}}$ & \\
\hline 18 & nya & $\mathrm{Z}$ & $\tilde{n} \tilde{n}$ & \\
\hline
\end{tabular}

Dalam penulisan aksara wianjana dikenal pula istilah tengenan, tengenan adalah aksara wianjana yang terletak pada akhir kata yang melambangkan fonem konsonan. Tengenan ini ditulis dengan pengangge tengenan serta gantungan atau gempelan untuk contoh penulisan tengenan serta contoh penulisannya dapat dilihat pada Tabel 2.3.

Tabel 2.3 : Pengangge Tengenan (Sumber : Nala, 2006).

\begin{tabular}{|l|l|c|l|}
\hline No & Aksara Latin & Pengangge Tengenan & Contoh Penggunaan \\
\hline 1 & ng (Cecek) & $\cdots \cdots \cdots * \cdots$ & bawang $=\mathrm{bw}^{*}$ \\
\hline 2 & r (Surang) & $\cdots \cdots \cdots \cdot($ & lawar $=\operatorname{lw}($ \\
\hline 3 & h (Bisah) & $;$ & barah $=\mathrm{br} ;$ \\
\hline 4 & Adeg-adeg & $/$ & anak $=\mathrm{hnk} /$ \\
\hline
\end{tabular}

\subsubsection{Angka dan Caciren Papaosan}

Dalam aksara Bali dikenal pula cara penulisan angka. Angka kosong atau nol ditulis seperti huruf o. Aksara satu ditulis seperti aksara ba, angka dua ditulis seperti aksara i, angka tiga seperti aksara au, dan seterusnya. Urutan angka untuk puluhan, ratusan, ribuan, dan seterusnya cara penulisannya hampir sama dengan tata cara dalam angka Latin. Angka dalam aksara Bali dapat dilihat pada Tabel 2.4. 
Tabel 2.4 : Penulisan Angka dalam Aksara Bali (Sumber : Nala, 2006).

\begin{tabular}{|l|l|l|l|l|l|}
\hline No & $\begin{array}{c}\text { Angka dalam } \\
\text { Huruf Latin }\end{array}$ & $\begin{array}{c}\text { Angka dalam } \\
\text { Aksara Bali }\end{array}$ & No & $\begin{array}{c}\text { Angka } \\
\text { dalam Huruf } \\
\text { Latin }\end{array}$ & $\begin{array}{c}\text { Angka dalam } \\
\text { Aksara Bali }\end{array}$ \\
\hline 1 & 1 & 1 & 6 & 6 & 6 \\
\hline 2 & 2 & 2 & 7 & 7 & 7 \\
\hline 3 & 3 & 3 & 8 & 8 & 8 \\
\hline 4 & 4 & 4 & 9 & 9 & 9 \\
\hline 5 & 5 & 5 & 0 & 0 & 0 \\
\hline
\end{tabular}

Sedangkan caciren papaosan adalah tanda baca dalam suatu tulisan. Bentuk caciren papaosan dapat dilihat pada Tabel 2.5.

Tabel 2.5 Caciren Papaosan (Sumber : Nala, 2006).

\begin{tabular}{|l|l|c|l|}
\hline No & Caciren Papaosan & Bentuk & \multicolumn{1}{|c|}{ Makna } \\
\hline 1 & Carik siki &, & Koma \\
\hline 2 & Carik kalih &. & Titik \\
\hline 3 & Pasalinan & .0. & Akhir naskah atau pergantian tembang \\
\hline 4 & Panten/Panti & $<$ & Tanda pada awal tulisan \\
\hline 5 & Cecek kalih & $:$ & Titik dua \\
\hline
\end{tabular}

\subsection{Analisis dan Perancangan}

Masalah yang akan diteliti adalah teknik mengkonversi dokumen dalam bentuk huruf Latin menjadi sebuah gambar dokumen dalam bentuk aksara Bali. Usulan solusi yang dapat diberikan untuk permasalahan tersebut dapat dibagi menjadi beberapa tahapan yang perlu dilakukan untuk dapat mengkonversi sebuah dokumen dalam huruf Latin menjadi sebuah gambar dokumen dalam bentuk aksara Bali yaitu sebagai berikut.

\subsubsection{Proses Menghitung Panjang Karakter}

Proses menghitung panjang karakter merupakan proses menghitung panjang karakter yang diinputkan oleh user yang nantinya akan digunakan untuk perulangan pengambilan suku kata dari dokumen yang diinputkan. Jika nilai yang dihasilkan pada proses menghitung panjang karakter bernilai 0 dengan kata lain user tidak menginputkan apapun, maka user diminta untuk menginputkan kembali dokumen yang 
ISSN 2089-8673

Jurnal Nasional Pendidikan Teknik Informatika (JANAPATI)

Volume 2, Nomor 1, Maret 2013

ingin dikonversi. Nilai yang dihasilkan pada proses menghitung panjang karakter akan digunakan untuk proses selanjutnya.

\subsubsection{Proses Memecah Suku Kata}

Proses memecah suku kata merupakan proses untuk memecah dokumen yang diiputkan oleh user menjadi suku kata. Proses memecah suku kata merupakan proses yang penting dalam aplikasi ini, seperti yang telah disebutkan sebelumnya aksara Bali menganut sistem silabik yaitu sistem suku kata. Proses memecah suku kata dilakukan berulang-ulang sesuai dengan nilai panjang karakter yang telah didapatkan pada proses sebelumnya. Namun jika ada penulisan yang tidak sesuai dengan ejaan bahasa Bali maka proses memecah suku kata kan dihentikan, contohnya pada penulisan raris ngranjing pada penulisan tersebut proses memecah suku kata akan dihentikan pada karakter ke-8 yaitu pada huruf óngô karena pada karakter tersebut ditemukan 3 suku kata konsonan yang saling mengikuti yaitu pada huruf s, ng, dan r. Penulisan aksara Bali hanya menanagani 1 buah gantungan saja, sehingga ketika proses memecah suku kata ditemukan 2 buah gantungan maka proses memecah suku kata dihentikan. Suku kata yang didapatkan pada proses ini akan digunakan pada proses selanjutnya.

\subsubsection{Proses Cek Suku Kata Asing}

Proses cek suku kata asing merupakan proses yang mengubah suku kata asing yang ditemukan pada proses memecah suku kata, misalnya jika ditemukan suku kata óiôakan diubah menjadi suku kata ópiô Ada beberapa huruf Latin yang tidak terdapat dalam aksara Bali yaitu, f, q, v, x, dan z. Tidak ada aturan khusus dalam mengubah suku kata asing menjadi ejaan aksara Bali, namun huruf-huruf yang tidak terdapat dalam aksara Bali akan dirubah sesuai dengan bunyi vokal dari huruf tersebut, musalnya huruf ápôpada pengucapan vokalnya sangat mirib dengan suku kata ókaô dalam aksara Bali, sehingga diharapkan tidak mengubah makna setelah diubah menjadi ejaan dalam bahasa Bali. Setelah proses cek suku kata asing selasai maka hasil dari proses tersebut akan dikembalikan ke proses memecah suku kata dan hasilnya akan digunakan pada proses selanjutnya. 
ISSN 2089-8673

Jurnal Nasional Pendidikan Teknik Informatika (JANAPATI)

Volume 2, Nomor 1, Maret 2013

\subsubsection{Proses Menentukan Posisi Suku Kata}

Proses menetukan posisi suku kata merupakan proses yang menentukan apakan suku kata yang ditemukan pada proses sebelumnya berada pada posisi talawia (atas), murdania (tengah), atau dantia (bawah). Huruf vokal i, ə otomatis berada pada posisi talawia, kemudian jika pada saat memotong suku kata terdapat suku kata yang mengikuti konsonan huruf óômaka huruf óômenjadi suku óurangôdan berada pada posisi talawia begitu pula dengan suku kata óngôakan berubah menjadi suku ácecekô dan posisinya berada pada posisi talawia. Contoh dari penulisan pada posisi talawia adalah misalnya diinputkan kata sartini maka pada proses memecah suku kata pada karakter ke-3 didapatkan huruf óô kemudian dilanjutkan dengan pengambilan suku kata yang ke-4 dan kembali ditemukan huruf konsonan yaitu áômaka huruf óôakan menjadi suku kata ósurangôdan diberikan posisi talawia. Ada perbedaan kondisi antara huruf óồdan óngô ónôakan berada pada posisi talawia jika seletah suku kata óngô ditemukan spasi atau karakter kosong.

Posisi murdania adalah posisi yang berada ditengah ï tengah. Aturan suku kata yang mendapatkan posisi murdania adalah aksara vokal selain aksara i dan ə serta jika aksara konsonan tepat berpasangan dengan aksara vokal tetapi tidak mengikuti aksara konsonan. Contohnya adalah pada penulisan kata ódewa AyuQ̂ pada proses pemotongan suku kata terdapat 4 suku kata yaitu đọ́̂ óvaô óAô dan óuô dalam proses pemotongan kata tidak ditemukan aksara konsonan yang mengikuti aksara konsonan sebelumnya jadi semua suku kata yang ditemukan pada proses pemotongan suku kata berada pada posisi murdania.

Posisi dantia adalah posisi penulisan aksara Bali yang berada paling bawah. Aksara yang sudah pasti berada pada posisi dantia adalah aksara óô suku kata yang mengikuti aksara konsonan pun akan berada pada posisi dantia atau dengan kata lain gantungan akan menempati posisi dantia. Posisi suku kata yang telah ditentukan akan digunakan pada proses selanjutnya. 
ISSN 2089-8673

Jurnal Nasional Pendidikan Teknik Informatika (JANAPATI)

Volume 2, Nomor 1, Maret 2013

\subsubsection{Proses Mencocokkan Suku Kata dengan Gambar Aksara Bali}

Proses mencocokan suku kata dengan gambar aksara Bali merupakan proses pengambilan gambar aksara Bali yang telah disimpan sebelumnya pada sebuah folder. Gambar yang telah ditemukan akan digunakan pada proses selanjutnya. Aksara Bali yang telah tersimpan dalam folder tersebut didapatkan dari printscreen dari Microsoft Word. Pemetaan huruf latin (dari keyboard) ke aksara Bali wianjana dapat dilihat pada Gambar 2.1, untuk pemetaan aksara suara dari keyboard ke aksara Bali dapat dilihat pada Gambar 2.2, untuk pemetaan angka dari keyboard ke aksara Bali dapat dilihat pada Gambar 2.3, untuk pemetaan gantungan dan gempelan dari keyboard ke aksara Bali dapat dilihat pada Gambar 2.4.

\begin{tabular}{|c|c|c|c|c|c|c|c|}
\hline Nama & Latin & \begin{tabular}{|l|} 
Pengetikan \\
\end{tabular} & Aks.Bali & Nama & Latin & Pengetikan & Aks.Bali \\
\hline ha & $\mathrm{h}$ & $\mathrm{h}$ & uv & la & 1 & 1 & $(2)$ \\
\hline na & $\mathrm{n}$ & $\mathrm{n}$ & 25 & pa & $\mathrm{p}$ & $\mathrm{p}$ & $u$ \\
\hline ca & c & c & 20 & ja & $\mathrm{j}$ & $\mathrm{j}$ & $r$ \\
\hline ra & $\mathrm{r}$ & $\mathrm{r}$ & 27 & ya & $\mathrm{y}$ & $\mathrm{y}$ & us \\
\hline $\mathrm{ka}$ & $\mathrm{k}$ & k & 8.1 & nya & ny & $\mathrm{z}$ & $m$ \\
\hline da & d & d & 2क & ma & $\mathrm{m}$ & $\mathrm{m}$ & (घ) \\
\hline ta & t & $\mathrm{t}$ & जo & ga & $\mathrm{g}$ & $\mathrm{g}$ & $(\Omega)$ \\
\hline sa & s & $\mathrm{s}$ & 21 & ba & b & b & $m$ \\
\hline wa & $\mathrm{w}$ & $\mathrm{w}$ & U & nga & $\mathrm{ng}$ & 1 & $m$ \\
\hline
\end{tabular}

Gambar 2.1 Pemetaan Aksara Wianjana pada Keyboard

\begin{tabular}{|c|c|c|}
\hline Bunyi & Pengetikan & Contoh \\
\hline $\mathrm{u}$ & $\mathrm{u}$ & $\mathrm{h}+\mathrm{u}=\boldsymbol{u} \mathrm{y}=\mathrm{hu}$ \\
\hline $\mathrm{e}$ & ) & $\mathrm{h}+)=\mathrm{Unn}_{\mathrm{n}}=\mathrm{he}$ \\
\hline $\mathrm{i}$ & $\mathrm{i}$ & $\mathrm{h}+\mathrm{i}={ }_{\text {थी }}=\mathrm{hi}$ \\
\hline o & e..o & $\mathrm{e}+\mathrm{h}+\mathrm{o}=\eta$ นnว $=h o$ \\
\hline é & $\mathrm{e}$ & $\mathrm{e}+\mathrm{h}=\eta \sim \Omega=h$ é \\
\hline
\end{tabular}

Gambar 2.2 Pemetaan Aksara Suara pada Keyboard 
ISSN 2089-8673

Jurnal Nasional Pendidikan Teknik Informatika (JANAPATI)

Volume 2, Nomor 1, Maret 2013

\begin{tabular}{|c|c|c|c|c|c|}
\hline Nama & Pengetikan & Aks.Bali & Nama & Pengetikan & Aks.Bali \\
\hline 1 & 1 & $v$ & 6 & 6 & a \\
\hline 2 & 2 & 2 & 7 & 7 & 0 \\
\hline 3 & 3 & 6 & 8 & 8 & U \\
\hline 4 & 4 & 3 & 9 & 9 & $\omega$ \\
\hline 5 & 5 & (3) & 0 & 0 & 0 \\
\hline
\end{tabular}

Gambar 2.3 pemetaan Angka pada Keyboard

\begin{tabular}{|c|c|c|c|c|c|}
\hline Nama & Pengetikan & Aks.Bali & Nama & Pengetikan & Aks.Bali \\
\hline ha & $\operatorname{ctrl}+^{`}+\mathrm{A}$ & 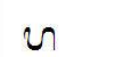 & la & Alt +0222 & $n$ \\
\hline na & $\operatorname{ctrl}+\wedge+\mathrm{A}$ & $\gamma$ & pa & $\mathrm{ctrl}+\&+\mathrm{a}$ & 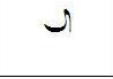 \\
\hline $\mathrm{ca}$ & $\operatorname{ctrl}+,+\mathrm{C}$ & U & ja & $\mathrm{ctr}+{ }^{\prime}+\mathrm{e}$ & $G$ \\
\hline ra & $\operatorname{ctrl}+{ }^{\prime}+\mathrm{E}$ & & ya & $\mathrm{ctr}+\wedge+\mathrm{e}$ & \\
\hline $\mathrm{ka}$ & $\operatorname{ctrl}+{ }^{\prime}+\mathrm{D}$ & 26 & nya & $\operatorname{ctrl}+\sim+\mathrm{n}$ & תרצי \\
\hline da & $\operatorname{ctrl}+\sim+\mathrm{N}$ & G & $\mathrm{ma}$ & $\begin{array}{c}\mathrm{CTRL}+\& \\
+\mathrm{S}\end{array}$ & C \\
\hline ta & $\mathrm{Ctrl}+{ }^{\prime}+\mathrm{O}$ & פ & ga & $\operatorname{ctrl}+{ }^{\prime}+a$ & $n$ \\
\hline sa & $\begin{array}{c}\mathrm{u} \text { ctrl }+\& \\
+\mathrm{a}\end{array}$ & $J^{-1}$ & ba & $\operatorname{ctrl}+\sim+\mathrm{a}$ & $m$ \\
\hline wa & ctrl $+{ }^{\circ}+\mathrm{U}$ & & nga & ctrl+@+a & $m$ \\
\hline
\end{tabular}

Gambar 2.4 Pemetaan Gantungan dan Gempelan pada Keyboard

\subsubsection{Proses Menempatkan Gambar Aksara Bali}

Proses menempatkan gambar aksara Bali merupakan proses akhir dari aplikasi text to digital image converter untuk dokumen aksara Bali. Gambar aksara Bali yang telah ditemukan sebelumnya akan ditempatkan pada posisi masing $\ddot{i}$ masing yang telah ditentukan pada proses sebelumnya. Pada tahap ini hanya menempatkan aksara Bali sesuai dengan suku kata kemudian dicocokkan dengan gambar aksara Bali yang telah 
ISSN 2089-8673

Jurnal Nasional Pendidikan Teknik Informatika (JANAPATI)

Volume 2, Nomor 1, Maret 2013

disimpan sebelumnya pada sebuah folder kemudian ditempatkan sesuai dengan posisi yang telah ditentukan pada proses sebelumnya.

\section{Pembahasan}

\subsection{Batasan Implementasi Perangkat Lunak}

Batasan implementasi dari aplikasi text to digital image converter untuk dokumen aksara Bali dapat dipaparkan sebagai berikut.

1. Format citra digital yang dihasilkan dari aplikasi ini adalah gambar dengan format bitmap (*.bmp).

2. Citra digital yang dihasilkan dari aplikasi ini adalah gambar dengan ukuran lebarnya 800 px untuk tingginya akan ditentukan sesuai dengan apa yang diinputkan oleh user.

3. Dalam aplikasi ini tidak menangani masalah perataan teks baik itu untuk rata kiri, rata kanan, rata tengan dan rata kiri-kanan.

4. Dalam aplikasi ini hanya mengkonversi aksara Bali Wreastra.

\subsection{Pelaksanaan Pengujian Perangkat Lunak}

Pengujian aplikasi text to digital image converter untuk dokumen aksara Bali dilakukan pada perangkat keras komputer dengan spesifikasi yang sama saat dikembangkannya perangkat lunak. Untuk kasus uji 1 sampai dengan kasus uji 8 manipulasi gambar yang dilakukan dengan bantuan perangkat lunak Microsoft Picture Manager dan Paint. Pengujian dilakukan sesuai dengan kasus uji yang telah dirancang sebelumnya untuk lebih jelasnya berikut akan dijabarnya detail pelaksanaan pengujian perangkat lunak.

\subsubsection{Pelaksanaan Kasus Uji 1}

Pada pengujian kasus uji 1 akan dilakukan dengan cara mengkonversi aksara suara atau aksara vokal yang terdapat dalam aksara Bali wreastra. Untuk detail pengujian kasus uji 1 dapat dilihat pada Tabel 3.1. 
Tabel 3.1 Hasil Pengujian Kasus Uji 1

\begin{tabular}{|c|c|c|c|c|c|}
\hline $\begin{array}{l}\mathbf{N} \\
\mathbf{0 .}\end{array}$ & $\begin{array}{c}\text { Aksara } \\
\text { Suara }\end{array}$ & $\begin{array}{c}\text { Gambar Hasil } \\
\text { Konversi }\end{array}$ & No. & $\begin{array}{c}\text { Aksara } \\
\text { Suara }\end{array}$ & $\begin{array}{c}\text { Gambar Hasil } \\
\text { Konversi }\end{array}$ \\
\hline 1. & $\mathrm{a}$ & n & 4. & $\mathrm{e}$ & pon \\
\hline 2. & $\mathrm{i}$ & in & 5. & o & puns \\
\hline 3. & $\mathrm{u}$ & $u y$ & 6. & $\partial$ & in \\
\hline
\end{tabular}

\subsubsection{Pelaksanaan Kasus Uji 2}

Pada pengujian kasus uji 2 akan dilakukan dengan cara mengkonversi aksara wianjana atau aksara konsonan yang terdapat dalam aksara Bali wreastra. Untuk detail pengujian kasus uji 2 dapat dilihat pada Tabel 3.2.

Tabel 3.2 Hasil Pengujian Kasus Uji 2

\begin{tabular}{|c|c|c|c|c|c|}
\hline No. & $\begin{array}{c}\text { Aksara } \\
\text { Winajana }\end{array}$ & $\begin{array}{c}\text { Gambar Hasil } \\
\text { Konversi }\end{array}$ & No. & $\begin{array}{c}\text { Aksara } \\
\text { Winajana }\end{array}$ & $\begin{array}{c}\text { Gambar Hasil } \\
\text { Konversi }\end{array}$ \\
\hline 1. & ha & un & 10. & ba & $\mathrm{b}$ \\
\hline 2. & na & 35 & 11. & $\mathrm{sa}$ & S \\
\hline 3. & $\mathrm{ca}$ & 27 & 12. & wa & W \\
\hline 4. & $\mathrm{ra}$ & 27 & 13. & la & 1 \\
\hline 5. & ka & 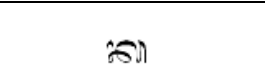 & 14. & $\mathrm{pa}$ & $\mathrm{p}$ \\
\hline 6. & ga & 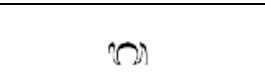 & 15. & $\mathrm{da}$ & $\mathrm{d}$ \\
\hline 7. & ta & जा & 16. & ja & $\mathrm{j}$ \\
\hline 8. & $\mathrm{ma}$ & ध) & 17. & ya & $\mathrm{y}$ \\
\hline 9. & nga & $m$ & 18. & nya & $\mathrm{Z}$ \\
\hline
\end{tabular}


ISSN 2089-8673

Jurnal Nasional Pendidikan Teknik Informatika (JANAPATI)

Volume 2, Nomor 1, Maret 2013

\subsubsection{Pelaksanaan Kasus Uji 3}

Pada pengujian kasus uji 3 akan dilakukan dengan cara mengkonversi gempelan dan gantungan aksara wianjana atau aksara konsonan yang terdapat dalam aksara Bali wreastra. Untuk detail pengujian kasus uji 3 dapat dilihat pada Tabel 3.3.

Tabel 3.3 Hasil Pengujian Kasus Uji 3

\begin{tabular}{|c|c|c|c|c|c|c|c|}
\hline No. & $\begin{array}{c}\text { Aksara } \\
\text { Winajan } \\
\qquad a\end{array}$ & $\begin{array}{c}\text { Gambar } \\
\text { Hasil } \\
\text { Konversi } \\
\text { Gantungan }\end{array}$ & $\begin{array}{c}\text { Gambar } \\
\text { Hasil } \\
\text { Konvers } \\
\text { i } \\
\text { Gempela } \\
n \\
\end{array}$ & No. & $\begin{array}{c}\text { Aksara } \\
\text { Winajan } \\
\qquad a\end{array}$ & $\begin{array}{c}\text { Gambar } \\
\text { Hasil } \\
\text { Konversi } \\
\text { Gantunga } \\
n\end{array}$ & $\begin{array}{c}\text { Gamba } \\
\text { r Hasil } \\
\text { Konver } \\
\text { si } \\
\text { Gempel } \\
\text { an } \\
\end{array}$ \\
\hline 1. & hha & "n & - & 10. & hba & $m$ & \\
\hline 2. & hna & $\mathrm{Cy}$ & & 11. & hsa & & 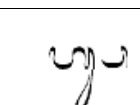 \\
\hline 3. & hca & ON & & 12. & hwa & un & \\
\hline 4. & hra & $\mathrm{U}$ & & 13. & hla & ת & \\
\hline 5. & hka & 25 & & 14. & hpa & & טn \\
\hline 6. & hga & nn & & 15. & hda & an & \\
\hline 7. & hta & ज़ & & 16. & hja & Gn & \\
\hline 8. & hma & Cي & & 17. & hya & $\mathrm{CM}$ & \\
\hline 9. & hnga & m & & 18. & hnya & 1n & \\
\hline
\end{tabular}

\subsubsection{Pelaksanaan Kasus Uji 4}

Pada pengujian kasus uji 4 akan dilakukan dengan cara mengkonversi pengangge tengenan yang terdapat dalam tata tulis aksara Bali. Pengangge tengenan adalah aksara wianjana yang terletak pada akhir kata yang melambangkan fonem konsonan. Untuk detail pengujian kasus uji 4 dapat dilihat pada Tabel 3.4. 
Tabel 3.4 Hasil Pengujian Kasus Uji 4

\begin{tabular}{|c|c|c|c|}
\hline No. & $\begin{array}{c}\text { Pengangge } \\
\text { Tengenan }\end{array}$ & Contoh Penulisan & Gambar Hasil Konversi \\
\hline 1. & ng (Cecek) & bawang & अभि \\
\hline 2. & r (Surang) & lawar & نे̀ \\
\hline 3. & h (Bisah) & barah & $\cos 27\}$ \\
\hline 4. & Adeg-adeg & anak & บ1185. \\
\hline
\end{tabular}

\subsubsection{Pelaksanaan Kasus Uji 5}

Pada pengujian kasus uji 5 akan dilakukan dengan cara mengkonversi sistem angka yang terdapat dalam tata tulis aksara Bali. Urutan angka untuk puluhan, ratusan, ribuan, dan seterusnya cara penulisannya hampir sama dengan tata cara dalam angka Latin. Untuk detail pengujian kasus uji 5 dapat dilihat pada Tabel 3.5.

Tabel 3.5 Hasil Pengujian Kasus Uji 5

\begin{tabular}{|c|c|c|c|c|c|}
\hline No. & Angka & $\begin{array}{c}\text { Gambar Hasil } \\
\text { Konversi }\end{array}$ & No. & Angka & $\begin{array}{c}\text { Gambar Hasil } \\
\text { Konversi }\end{array}$ \\
\hline 1. & 1 & mi & 8. & 8 & 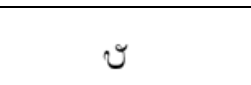 \\
\hline 2. & 2 & 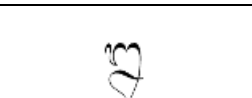 & 9 & 9 & $w$ \\
\hline 3. & 3 & $\infty$ & 10. & $\mathbf{0}$ & 0 \\
\hline 4. & 4 & 3 & 11. & 17 & ming \\
\hline 5. & 5 & (3) & 12. & 123 & mingen \\
\hline 6. & 6 & $a$ & 13. & 1945 & mivo 3 () \\
\hline 7. & 7 & צטי & & & \\
\hline
\end{tabular}




\subsubsection{Pelaksanaan Kasus Uji 6}

Pada pengujian kasus uji 6 akan dilakukan dengan cara mengkonversi tanda baca atau yang disebut dengan caciren papaosan yang terdapat dalam tata tulis aksara Bali dan disertai dengan contoh penulisan pada aplikasi. Untuk detail pengujian kasus uji 6 dapat dilihat pada Tabel 3.6.

Tabel 3.6 Hasil Pengujian Kasus Uji 6

\begin{tabular}{|c|c|c|c|}
\hline No. & $\begin{array}{c}\text { Caciren } \\
\text { Papaosan }\end{array}$ & $\begin{array}{c}\text { Contoh } \\
\text { Penulisan }\end{array}$ & Gambar Hasil Konversi \\
\hline 1. & Carik siki & Aksara Bali, & 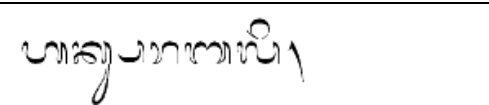 \\
\hline 2. & Carik kalih & Aksara Bali. & 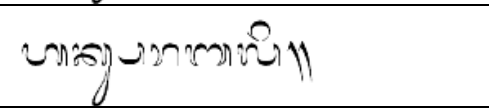 \\
\hline 3. & Pasalinan & Aksara Bali> & 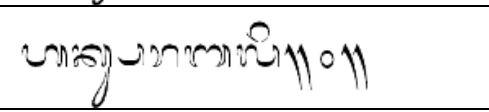 \\
\hline 4. & Panten/Panti & $<$ Aksara Bali & นาง \\
\hline 5 & Carik kalih & Aksara Bali : & 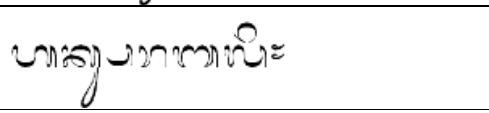 \\
\hline
\end{tabular}

\subsubsection{Pelaksanaan Kasus Uji 7}

Pada pengujian kasus uji 7 akan dilakukan dengan cara mengkonversi dokumen dari dokumen tersebut akan di uji kebenaran dalam memecah suku kata yang diinputkan. Dokumen yang akan diinputkan hanya terdiri dari beberapa kata, hanya untuk mengetahui ketepatan program dalam memecah suku kata dari sebuah dokumen. Untuk detail pengujian kasus uji 7 dapat dilihat pada Tabel 3.7.

Tabel 3.7 Rancangan Kasus Uji 7

\begin{tabular}{|c|c|c|}
\hline No. & Dokumen & Hasil Konversi \\
\hline 1. & 12, Pupuh Ginada. & minglyyjâmin \\
\hline 2. & $\begin{array}{l}\text { I Dewa Ayu Made } \\
\text { Sartini }\end{array}$ & 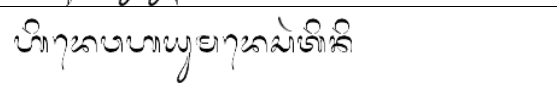 \\
\hline 3. & $\begin{array}{l}\text { Driki tityang nguntul } \\
\text { ngebiosang yéh mata }\end{array}$ & 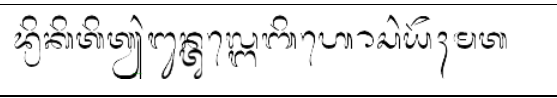 \\
\hline
\end{tabular}




\begin{tabular}{|c|c|c|}
\hline No. & Dokumen & Hasil Konversi \\
\hline 4. & $\begin{array}{l}\text { Duk punika tahun } \\
1945\end{array}$ & 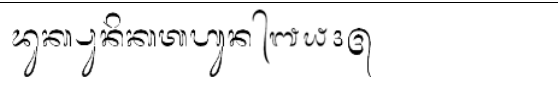 \\
\hline
\end{tabular}

\subsubsection{Pelaksanaan Kasus Uji 8}

Pada pengujian kasus uji 8 akan dilakukan dengan cara mengkonversi dokumen yang terdapat suku kata asing dari dokumen tersebut akan di uji kebenaran dalam memecah suku kata yang diinputkan serta mengubah kedalam ejaan penulisan aksara Bali. Dokumen yang akan diinputkan hanya terdiri dari beberapa kata, hanya untuk mengetahui ketepatan program dalam memecah suku kata serta mengubah ke dalam ejaan penulisan aksara Bali. Untuk detail pengujian kasus uji 8 dapat dilihat pada Tabel 3.8 .

Tabel 3.8 Rancangan Kasus Uji 8

\begin{tabular}{|c|c|c|}
\hline No. & Dokumen & $\begin{array}{rr}\text { Hasil Konversi } \\
\end{array}$ \\
\hline 1. & $\begin{array}{l}\text { Kudang quintal meli } \\
\text { uyah }\end{array}$ & 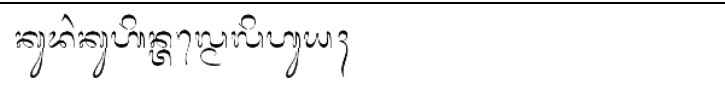 \\
\hline 2. & $\begin{array}{l}\text { I nyoman mebalih } \\
\text { film }\end{array}$ & 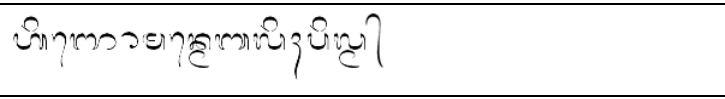 \\
\hline 3. & $\begin{array}{l}\text { Voting dados anggen } \\
\text { solusi }\end{array}$ & 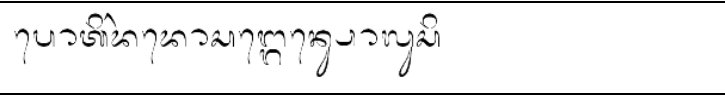 \\
\hline 4. & $\begin{array}{l}\text { Jani lakar meli } \\
\text { mobil xenia baru }\end{array}$ & 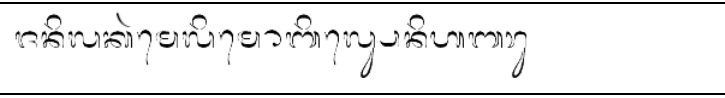 \\
\hline 5 & $\begin{array}{l}\text { Tahu ne ento misi } \\
\text { zat berbahaya, } \\
\text { tusing dadi daar }\end{array}$ & 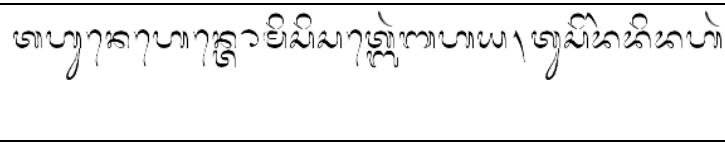 \\
\hline
\end{tabular}

\subsubsection{Pelaksanaan Kasus Uji 9}

Pada pengujian kasus uji 9 akan dilakukan dengan cara mengkonversi dokumen aksara Bali. Dokumen aksara Bali yang akan dikonversi akan disesuaikan untuk ukuran kertas A4 tanpa merubah bentuk dari gambar asli yang akan dihasilkan dari proses konversi dokumen tersebut. Hal ini dilakukan untuk mengetahui kualitas gambar yang dihasilkan dari proses konversi. Dokumen yang akan dikonversi dapat dilihat pada Gambar 3.1, sedangkan untuk hasil konversi dapat dilihat pada Gambar 3.2 


\section{$<$ SUMPAH PALAPA $<$}

Sapamade*g Ida Sri Jaya Nagari Majapahit, makeh byutene irika, santukan Ida nenten adil ngambel jagat. Byuta kaping siki olih Rangga Lawe, Adipati Tuban, Santukan dane nenten kadadosang patih Majapahit. Rangga Lawe prasida kakawonang duk warsa 1309 Masehi. Byuta kaping kalih ngawit warsa, 1311, masehi, kapucukin olih Rakrian Majapahit sane mapesengan Sora, taler prasida kakawonang. Byuta kaping tiga ngawit warsa, 1316, olih Patih Majapahit sane mapesengan Nambi, Putran Arya Pranaraga, Patih Nambi makarya gelar ring Pajarakan. Rames pisan yuddane irika, ngantos Patih Nambi sakulawargan dane brasta sami. Byuta kaping pat warsa 1319 masehi, sane kapucukin olih Kuti, byuta puniki mabuat pisan. Dane prasidda ngranjing kapuser Kuta Majapahite, punika mawinan Ida Sri Jaya Nagara ka gingsir rang ka desa Bedander, kaabih olih 15 Bayangkari sane kapucukin olih Bekel Mada, usan punika Bekel Mada raris ngeranjing ka Kuta Majapahit, ngrereh parajurite sane kantun sutindih ring Jaya Nagara, dane raris ngadakang yudda ngwale*s pengamuk Kutine ngantos kakawonang. Sumpah Palapa punika kalaksanayang ngawit warsa 1343 , kakawitin antuk ngadakang payuddan ka jagat Baliò

Gambar 3.2 Dokumen dalam Bentuk Huruf Latin 
ISSN 2089-8673

Jurnal Nasional Pendidikan Teknik Informatika (JANAPATI)

Volume 2, Nomor 1, Maret 2013

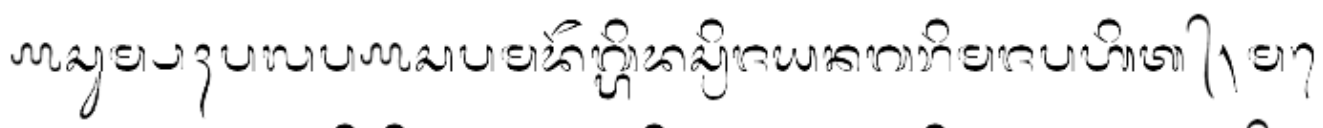

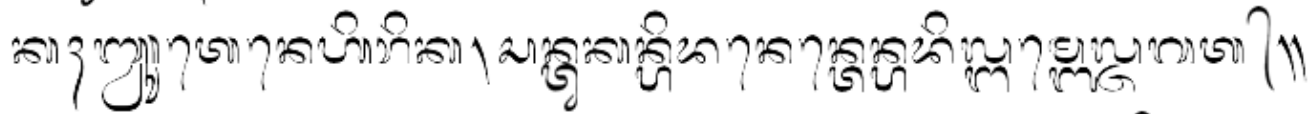

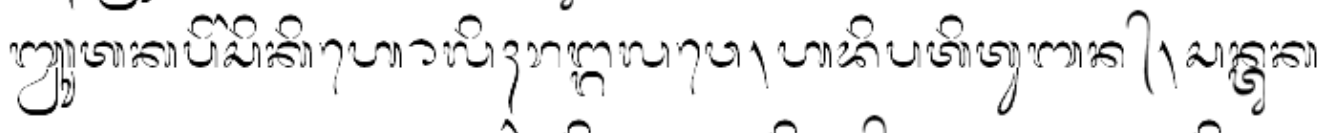

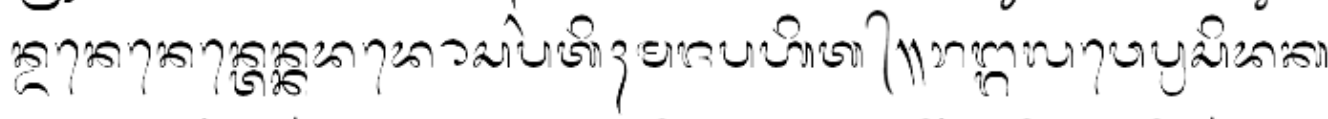

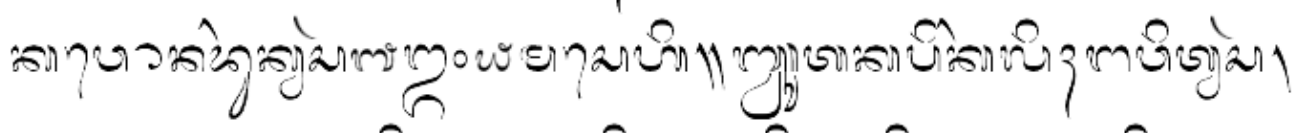

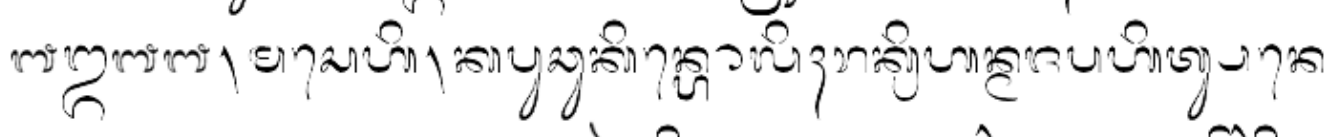

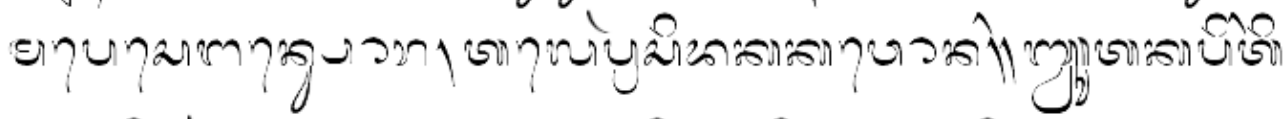

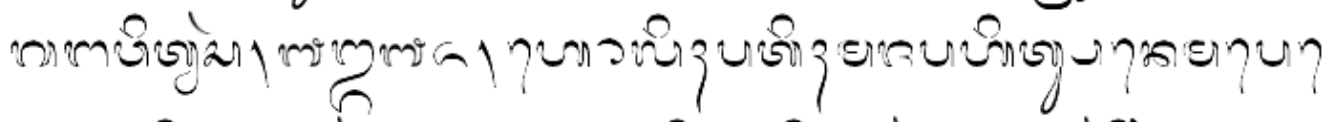

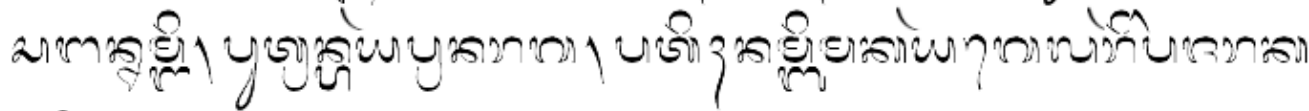

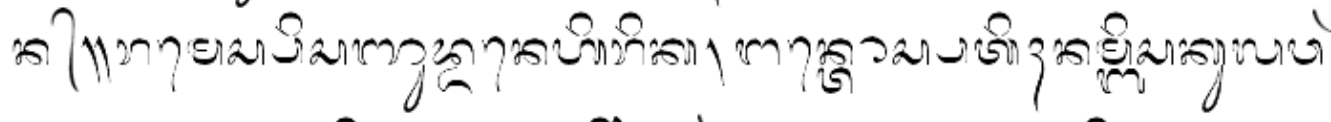

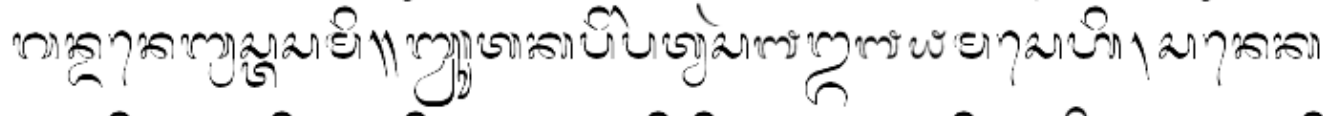

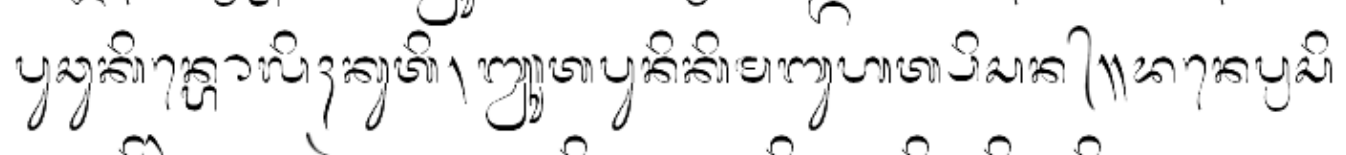

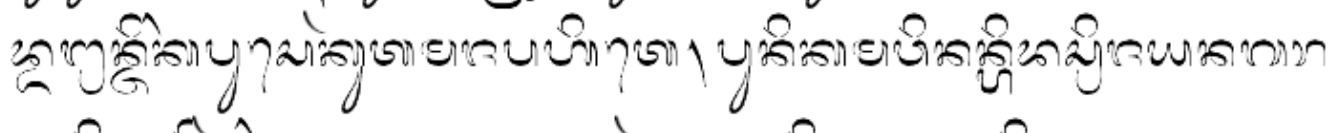

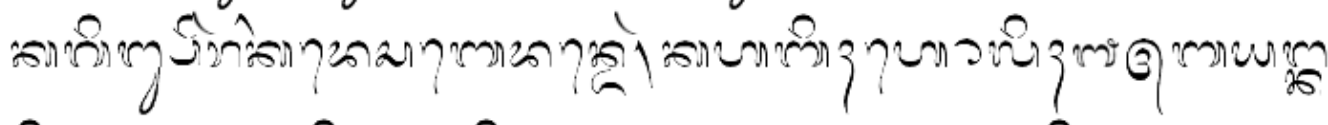

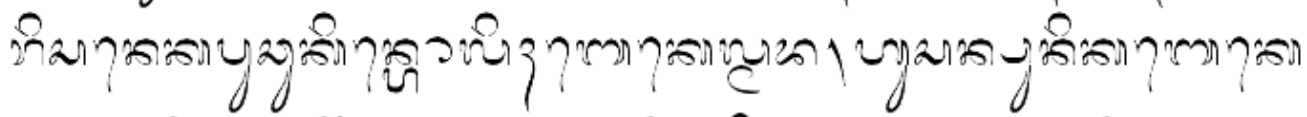

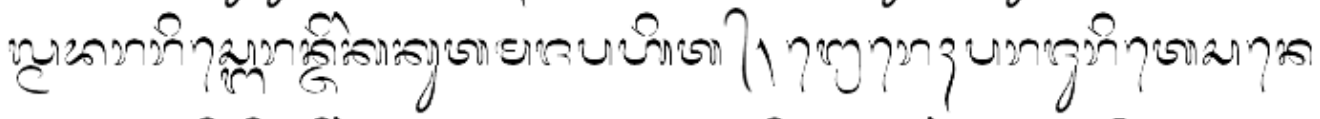
ลง

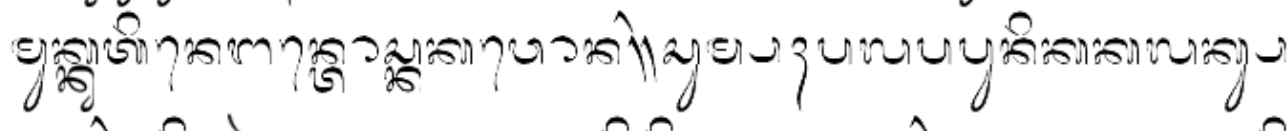

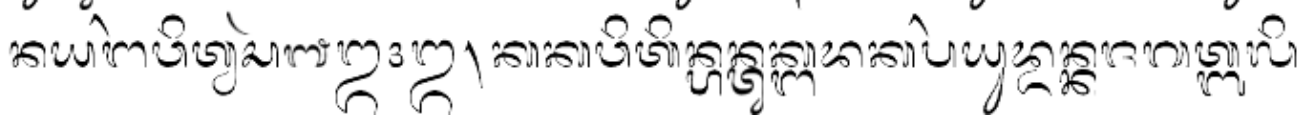

Gambar 3.2 Hasil Konversi Dokumen Aksara Bali 
ISSN 2089-8673

Jurnal Nasional Pendidikan Teknik Informatika (JANAPATI)

Volume 2, Nomor 1, Maret 2013

\section{Penutup}

\subsection{Kesimpulan}

Berdasarkan penelitian pengembangan aplikasi text to digital image converter untuk dokumen aksara Bali yang telah dilakukan adapun simpulan yang didapat antara lain.

1. Rancangan sistem aplikasi text to digital image converter untuk dokumen aksara Bali digambarkan menggunakan DFD (Data Flow Diagram). DFD yang dibuat meliputi DFD level 0, dan DFD level 1.

2. Rancangan antarmuka yang telah dibuat pada pengembangan aplikasi text to digital image converter untuk dokumen aksara Bali yaitu rancangan antarmuka form utama, rancangan antarmuka form input document, rancangan antarmuka form about programer, rancangan antarmuka form about program.

3. Implemantasi aplikasi text to digital image converter untuk dokumen aksara Bali menghasilkan suatu program aplikasi yang mengkonversi dokumen aksara Bali dari huruf Latin menjadi sebuah gambar aksara Bali.

4. Perangkat lunak yang dibangun dapat dijadikan sebagai suatu aplikasi konversi aksara Bali. Dilihat dari gambar yang dihasilkan penulisan aksara Bali sudah sesuai dengan aturan penulisan, serta kualitas gambar yang baik.

\section{Daftar Pustaka}

Belza Achmad, Kartika Firdausy. 2005. Teknik Pengolahan Citra Digital Menggunakan Delphi. Yogyakarta : Ardi PubliShing

Nala, Ngurah. 2006. Aksara Bali dalam Usada. Surabaya : Penerbit Paramita

Rustan. 2008. ñMakalah Perubahan Kebudayaan Karena Pengaruh Luarò. http://isbdti.blog.uns.ac.id/2009/11/09/makalah-perubahan-kebudayaan-karenapengaruh-dari-luar/. (diakses tanggal 26 Desember 2011)

Sutoyo, T., dkk. 2009. Teori Pengolahan Citra Digital. Yogyakarta : Penerbit Andi 
ISSN 2089-8673

Jurnal Nasional Pendidikan Teknik Informatika (JANAPATI)

Volume 2, Nomor 1, Maret 2013

Trajianto. 2010. òPemrograman Lanjutan Delphi 7.0ò http://tarjianto.files.wordpress.com/2010/03/perulangan-if-then-else-padadelphi.pdf. (diakses 23 Maret 2011)

Tinggen, I Nengah. 1993. Celah - Celah Kunci Pasang Aksara Bali. Singaraja : Penerbit Indra Jaya.

Umi Probeyekti. 2008. ÒBahan Ajar Rekaya Perangkat Lunak Software Process Model Iò. http://lecturer.ukdw.ac.id/othie/softwareprocess.pdf. (diakses tanggal 2 Januari 2012) 